\title{
Cefamandole - A Competitive Inhibitor of Aldehyde Dehydrogenase
}

Cefamandole (CMD), a betalactam antibiotic with a l-methyl-tetrazole-5-thiol group, evokes in man a disulfiram-like alcohol incompatibility with flush, tachycardia, hypotension and nausea $(1,2)$. An accumulation of acetaldehyde (ethanol metabolite) is thought to be responsible for these symptoms (disulfiram-like reaction). This explanation is derived from an increase in the acetaldehyde concentration found in the blood of alcoholized experimental rats after pretreatment with CMD (3-5). The increase of the acetaldehyde concentration in blood is caused by an inhibition of aldehyde dehydrogenase $(\mathrm{ALDH})$ by $\mathrm{CMD}$, as found in vitro with low- $\mathrm{K}_{\mathrm{m}} \mathrm{ALDH}$ preparations from rat liver (5). The inhibition of the ALDH activity is of a competitive character, as shown by the results of our enzyme-kinetic investigations (Figure $1)$.

Our experiments were carried out with isolated ALDH from the livers of female Sprague-Dawley rats $(230 \mathrm{~g}$; breeding station and holding conditions described elsewhere [6]) using a conventional method (7) modified as follows: The hepatic microsomes and mitochondria containing fraction (preparation described previously [8]) were resuspended in a 3\% EDTA solution (for inactivation of NADH-consuming systems) with glutathion (0.6\%; for protection against ALDH oxidation) and ultracentrifuged $\left(105,000 \times \mathrm{g} ; 30 \mathrm{~min} ; 4^{\circ} \mathrm{C}\right)$. The sediment was resuspended in an Na-phosphate buffer pH $7.4(0.2$ m) containing 1\% Triton (to solubilize the ALDH from the lipid membranes of the cell organelles), and ultracentrifuged $\left(105,000 \times \mathrm{g} ; 30 \mathrm{~min} ; 4^{\circ} \mathrm{C}\right)$ again after one hour $\left(0^{\circ} \mathrm{C}\right)$. The amount of protein in the ALDH containing supernatant was determined (standard: albumin, bovine, fraction V; Sigma, St. Louis/U.S.A.) with Folin reagent

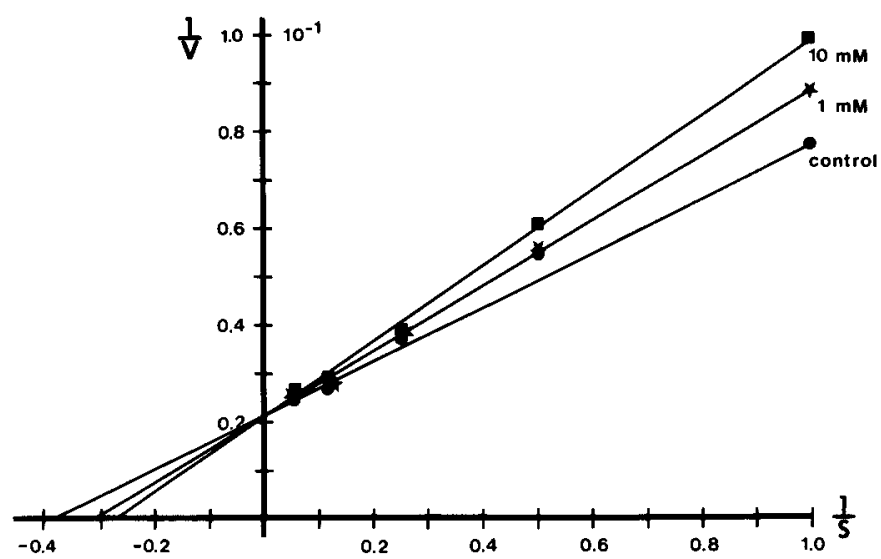

Figure 1: Lineweaver-Burk diagram (10) of the enzymekinetic values under the influence of CMD on isolated ALDH from rat liver. Each point on the curves was determined from eight observations (using parts of eight rat livers). $V_{\max }=49 \mathrm{nmol} / \mathrm{mg}$ protein $/ \mathrm{min} ; \mathrm{K}_{\mathrm{m}}=2.7 \mathrm{mM}$ (control), $3.3 \mathrm{mM}$ (1 mM CMD), $3.8 \mathrm{mM}$ (10 mM CMD).
(9). The in vitro reaction mixture contained successively: $500 \mu \mathrm{K}_{2} \mathrm{HPO}_{4}$ buffer $\mathrm{pH} 9.2(0.5 \mathrm{M}) ; 100 \mu \mathrm{l} \mathrm{NAD}$ solution $(0.02 \mathrm{M}) ; 100 \mu \mathrm{l}$ ALDH (3 mg protein $/ \mathrm{ml}) ; 290,280$, 260, 220 and $140 \mu \mathrm{l}$ doubly distilled water (blank: $300 \mu \mathrm{l}$, $100 \mu \mathrm{l}$ less in CMD containing reaction mixtures); $100 \mu \mathrm{l}$ CMD solution (variable concentration in doubly distilled water); $10,20,40,80$ and $160 \mu \mathrm{l}$ acetaldehyde solution $(0.1 \mathrm{M})$ (blank: 0$)$. The NADH produced was determined spectrophotometrically $(346 \mathrm{~nm})$ and the ALDH activity (nmol acetaldehyde/mg protein $/ \mathrm{min}$ ) measured. CMD was purchased from Eli Lilly, Gießen, F.R.G., the other reagents from Merck, Darmstadt, F.R.G.

The small augmentation (Figure 1) of $\mathrm{K}_{\mathrm{m}}$ (Michaelis constant) with constant $\mathrm{V}_{\max }$ (maximum transformation velocity) following both realistic inhibitor concentrations of 1 and $10 \mathrm{mM} \mathrm{CMD}$, respectively, is indicative of a small and competitive inhibition of ALDH. Although we are aware of the problems involved in transferring results from animal studies to human beings, this characteristic explains the incompatibility of CMD with alcohol $(1,2)$ that may appear during CMD therapy and is known to be of short duration and limited extent.

\section{K. J. Freundt, E. Schreiner, U. Christmann-Kleiss}

\section{Literature}

1. Drummer, S., Hauser, W. E., Remington, J. S.: Antabuse-like effect of $\beta$-lactam antibiotics. New Engl. J. Med. 303 (1980) $1417-1418$.

2. Portier, H., Chalopin, J. M., Freysz, M., Tanter, Y.: Interaction between cephalosporins and alcohol. Lancet II (1980) 263.

3. Buening, M. K., Wold, J. S., Israel, K. S., Kammer, R. B.: Disulfiram-like reaction to $\beta$-lactams. JAMA 245 (1981) 2027.

4. Yanagihara, M., Okada, K., Nozaki, M., Tsurumi, K., Fujimura, H.: Disulfiram-like reaction resulting from intravenous administration of cephem antibiotics. Folia Pharmacol. Japon. 79 (1982) 551-560.

5. Yamanaka, Y., Yamamoto, T., Egashira, T.: Effects of cephem antibiotics on rat liver aldehyde dehydrogenases. Japan. J. Pharmacol. 33 (1983) 717-723.

6. Römer, K. G., Torres Alanis, O., Garcia de Torres, G., Freundt, K. J.: Delayed ethanol elimination from rat blood after treatment with thiram, tetramethylthiuram monosulfide, ziram, or cyanamide. Bull. Environ. Contam. Toxicol. 32 (1984) 537-542.

7. Lundquist, F.: Bestimmung mit Aldehyd-Dehydrogenase. In: Bergmeyer, H. U. (ed.): Methoden der enzymatischen Analyse. Band II. Verlag Chemie, Weinheim 1974, pp. 1555-1559.

8. Kromer, W., Freundt, K. J.: Hemmung der oxidativen N-Demethylierung in vitro durch Schwefelkohlenstoff. Arzneim.-Forsch. Drug Res. 26 (1976) 189-194.

9. Lowry, O. H., Rosebrough, N. J., Farr, A. L., Randall, R. J.: Protein measurement with Folin phenol reagent. J. Biol. Chem. 193 (1951) 265-275.

10. Bisswanger, H.: Theorie und Methoden der Enzymkinetik. Verlag Chemie Weinheim, Deerfield Beach/Florida, Basel 1979, pp. 81-82.

Prof. Dr. K. J. Freundt, E. Schreiner, Dr. U. Christmann-Kleiss, Institute of Pharmacology and Toxicology, Faculty of Clinical Medicine Mannheim, University of Heidelberg, Maybachstrasse 14-16, D-6800 Mannheim 1. 